\title{
Regimes of waste (im)perceptibility in the life cycle of metal
}

\author{
By Michael Hennessy Picard* \& Tina Beigi**
}

\begin{abstract}
This article describes how the transnational legal landscape governing waste management, recycling, and disposal remains narrowly focused on the economic possibilities of 'end-of-life products', while paying little to not consideration to the much greater quantities of waste generated at the beginning of the product's lifecycle. The article thus explores the existing regulatory framework through the notions of visible and invisible: while the circular economy of recycling increasingly integrates synthetic waste into the visible, the extractive industry buries biophysical waste into a 'cradle-to-grave' economy. We argue that waste becomes a perceptible matter of concern when commodified into a new cycle of wealth accumulation. By contrast, when waste is abandoned on mining sites or spread as microparticles in the atmosphere, it becomes an imperceptible matter of fact. Mining risks, although perceptible to the industry and affected communities, are rendered less visible to the administrative bodies in charge of regulating them. The article finds that waste (im)perceptibility is industrially manufactured according to the commercial aspects of a product, rather than its toxicity.
\end{abstract}

When crimes start to accumulate, they become invisible. Berthold Brecht ${ }^{1}$

\section{Introduction}

At the turn of the century, Chile's National Commission of the Environment (CONAMA) gave permission to the Canadian mining corporation Barrick Gold to move three glaciers out of the Pascua Lama goldmining site. Though the project was soon cancelled out of the sheer impossibility to physically relocate the century-old glaciers, it glaringly exposed how nature is rendered politically invisible in the Global South in response to foreign mining interests. ${ }^{2}$ Around the same time, the first comprehensive reports on discarded electronics started to raise awareness of their environmental and social impact, which provided the context in which the need to regulate e-waste emerged. Today, consumers in shopping malls around the world are invited to drop their old cell phones in dedicated recycling bins, as part of an increasingly popular waste management strategy known as the 'circular economy'. At the forefront of such initiatives, the European Commission's Circular Economy Action Plan intends to 'close the loop' by incorporating electronic wastes

\footnotetext{
${ }^{*}$ Institute of Advanced Studies, University College London, m.picard@ucl.ac.uk.

** McGill University, tina.mohammadbeygy@ mail.mcgill.ca. We wish to thank the TLT reviewers and editors, Emily Webster and Phillip Paiement, for their careful reading of previous versions of this article and for their thoughtful and generous comments. The 2018-19 Harvard STS Fellows and the (In)visibilities 2019 Binocular Conference in Toronto offered enlightening feedback on early drafts. This research was also supported by the Leadership for the Ecozoic project (L4E) at McGill University. All websites accessed 3 June 2020.

${ }^{1}$ Brecht Bertolt, Bertolt Brecht Poems (vol 1, Eyre Methuen 1976).

2 Javiera Barandiarán, Science and environment in Chile: The politics of expert advice in a neoliberal democracy (MIT Press 2018) 127.
} 
within existing recycling markets and 'help consumers choose sustainable products' ${ }^{3}$ However, the waste and substances identified in such circular economy regimes represent only a tiny fraction of the chemical, toxic, and hazardous products generated by the global supply chain of electronics. Since most of the toxic waste arising from electronics production occurs before consumers even purchase the commodity, household recycling programs and zero-waste initiatives - commendable as they may be - will do little to mitigate industrial-scale waste generation. The Canadian geographer Josh Lepawsky offers one revealing example of the disproportionate amount of waste generated at the pre-consumption stage: one single smelter producing metals for electronics in Mexico generates almost twice the amount of e-waste exported by the United States annually. As a result, 'waste arising from electronics manufacturing vastly exceeds that arising from postconsumer discards. ${ }^{4}$

These examples demonstrate a fragmented political economy of waste, where some peripheral sources of environmental degradation become 'sights unseen', ${ }^{5}$ while others are commodified, valued and made visible. Regulatory concern is generally addressed by post-consumption recycling policies and rarely tackles the problem directly at the source of mineral extraction. ${ }^{6}$ Could it be that the cosmology of industrial waste is split into two opposites, the invisible life and the visible life, which co-evolve dialectically across global chains of production and consumption? If so, what are the laws and dynamics ruling over the invisible life and the visible life? How is the material world of mineral and electronic discards normatively (dis)ordered $?^{7}$ Our research wishes to call the reader's attention to the making and un-making of these (in)visible spheres. We further investigate the blind spots, ambiguities and contradictions created by the legal categories of waste in the life cycle of metal.

In an influential article ${ }^{8}$, Bruno Latour voices his concern about climate change scepticism, which questions the reality of global warming. He laments the fact that sceptics now use the same very argument of 'social construction', tools of epistemological doubt, and flawed objectivity, which Latour himself had developed - which he dubs matters of concern — to wage a war against hard-won evidence that could save our lives. At first, Latour's critique of science had called on scholars to question the presumption of naturalised objectified facts. Yet, at the turn of the twenty-first Century, such a critique was becoming instrumentalised by vested interests in Washington to deny the best available scientific data on

\footnotetext{
3 For more information, see the European Commission's portal on the circular economy, available online: https://ec.europa.eu/environment/circular-economy/index_en.htm

${ }^{4}$ Josh Lepawsky, Reassembling rubbish: worlding electronic waste (MIT Press 2018) 142.

${ }^{5}$ Scott Frickel \& James Elliott, Sites unseen: uncovering hidden hazards in American cities (Russell Sage Foundation 2018).

${ }^{6}$ In this article, the source refers to the waste generated by transnational industrial conglomerates, which are logistically designed to extract, store, refine, manufacture, and distribute minerals. Primary sources of upstream pollution are attributed to any matter, whether liquid, solid, gaseous or radioactive, which is discharged, emitted, or deposited in the environment in such volume, composition or manner as to cause an alteration of the environment. ${ }^{6}$ Examples include mining waste (waste rock, mineral, processing chemicals), gas and petroleum waste from extraction (drilling fluids and cuttings like complex mixtures of clays and chemicals) as well as $\mathrm{CO}_{2}$ emission, water pollution, for example. There are also secondary sources of downstream leakage (which, for the purpose of our study, is concerned with - but not limited to - the postconsumer stage), such as recyclable solid waste containing plastic, cardboard, glass, paper, aluminium, and minerals such as e-waste.

${ }^{7}$ Neil Walker, 'Beyond boundary disputes and basic grids: Mapping the global disorder of normative orders' (2008) 6(3-4) International Journal of Constitutional Law 373.

${ }^{8}$ Bruno Latour, 'Why has critique run out of steam? From matters of fact to matters of concern' (2004) 30(2) Critical inquiry 225; for recent discussion see Gareth Leng \& Rhodri Ivor Leng (eds), The Matter of Facts: Skepticism, Persuasion, and Evidence in Science (MIT Press 2020).
} 
environmental boundaries — considered matters of fact — upon which the Anthropocene is encroaching. ${ }^{9}$ Latour suggests that, for the critical mind to become relevant again, scholars must attempt to deal with matters of concern. To be critical is not to debunk, but to assemble and reassemble. ${ }^{10}$

Following Latour's theory of assemblage, we intend to start collecting fragmented knowledges and norms about hazardous waste and focus on the sets of regulations and policies, which organise and sustain the (in)visibility of waste. According to our binary classification, what we call 'matter of fact' is the volume of toxic extractive waste and the materiality of its distribution, whereas the phrase 'matter of concern' refers to the relevant laws of waste management and mitigation. As demonstrated by the chart below, there is an inverted correspondence between the seriousness of a privately manufactured hazard and the amount of public attention it receives. The legality (matters of concern) does not only fail to reflect the materiality of waste (matter of fact), it also obscures its uneven distribution.

\section{Matter of fact \\ Materiality of waste distribution}

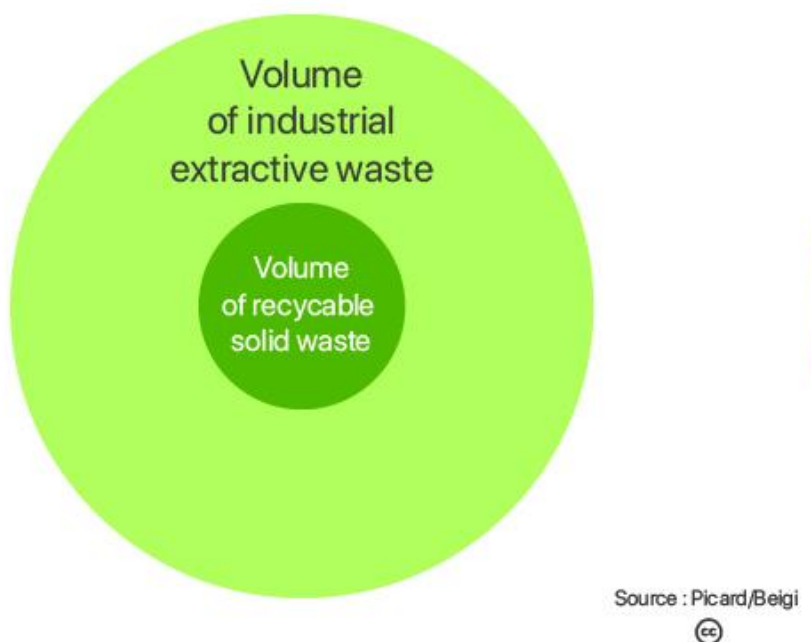

\section{Matter of concern Legality of waste management}

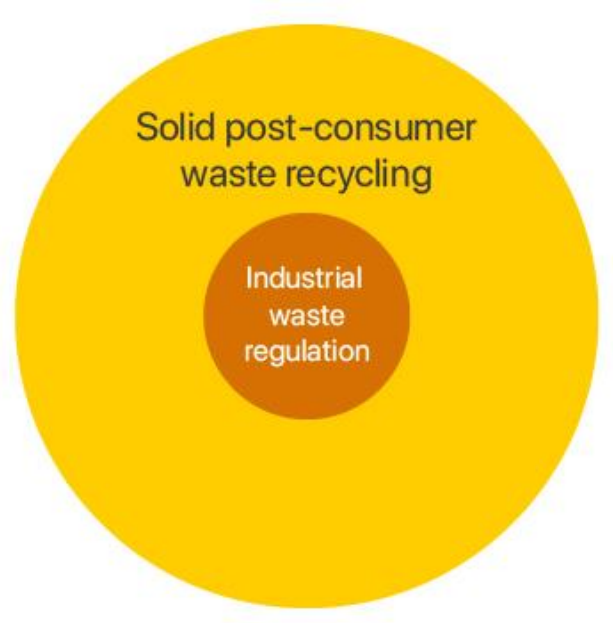

The chart above illustrates the classification of imaginaries in global waste management. On the left hand, the volume of industrial extractive waste is shown by the larger circle to demonstrate its significantly massive scope, globally 100 billion tonnes per year compared to only 500 million tonnes of recyclable e-waste represented by the smaller circle. On the right hand, the legality of waste management shifts societal concerns to e-waste by producing more and more stringent laws and regulation pertinent to this type of discard as it gains more and more economic value. By contrast, laws rulings over industrial waste are represented in the smaller circle depicting the dearth of rigour to mitigate environmental pollution at the source.

In other words, the current matter of concern foregrounds postconsumer waste, while simultaneously backgrounding the fact that industrial waste is far more voluminous and toxic than postconsumer waste.

\footnotetext{
${ }^{9}$ Will Steffen et al, 'Planetary boundaries: Guiding human development on a changing planet' (2015) 347(6223) Science 1259855.

${ }^{10}$ Latour (n 8).
} 
Visibility and invisibility are co-produced, as one illuminated feature of the e-waste mining economy simultaneously obscures other features of the mineral supply chain. Waste becomes a perceptible matter of concern, when commodified into a new round of wealth accumulation. On the contrary, when waste is abandoned on mining sites or spread as microparticles in the atmosphere, it becomes an imperceptible matter of fact.

A growing body of scientific literature known as 'agnotology' — the study of ignorance - points to the socially constructed blindness towards ecological hazard manufactured by powerful industries, such as the tobacco, petrochemical and mining sectors. ${ }^{11}$ Active ignorance is deliberately orchestrated by 'science wars ${ }^{12}$ to forestall regulation of polluting industries, 'jam the scientific airwaves', produce uncertainty and divergent interpretation of evidence, which question scientifically established consensus by setting up impossible standards of proof. As we shall see, mining risks, although perceptible to the industry and affected communities, are rendered less visible to the administrative bodies in charge of regulating them. ${ }^{13}$

Powerful lobbies work hard to keep the hazardous industrial pollution outside the purview of global regulatory reform, while highlighting their otherwise voluntary participation in municipal e-waste recovery schemes. ${ }^{14}$ For instance, though toxic nickel sulphates may be regulated and controlled by a 2007 European Union regulation, their widespread usage is still allowed and facilitated by a close association between industrialists and regulators. ${ }^{15}$ Transnational governance relating to waste internalises the managerial logic of the market, by rejecting mining waste as a 'negative externality' at the source of extraction and monetising it as recoverable e-waste at the sink of consumption. ${ }^{16}$ As a result, waste (im)perceptibility is manufactured according to the commercial aspects of a product, rather than its toxicity. ${ }^{17}$

Before addressing the specific legal regimes of e-waste management (2) and mining waste evacuation (3) in the life cycle of metal, the following section provides theoretical insights on the asymmetry of waste perception framed by legal (dis)orderings (1).

\section{Asymmetry of perception framed by legal (dis)orderings}

\footnotetext{
${ }^{11}$ Janet Kourany and Martin Carrier (eds), Science and the Production of Ignorance: When the Quest for Knowledge Is Thwarted (MIT Press 2020).

12 The term science wars refer to a complex of intellectual exchanges and strong polarization over questions of intellectual legitimacy and scientific authority in the mid-1990s.

${ }^{13}$ Kourany \& Carrier (n 11).

${ }^{14}$ François Jarrige and Thomas Le Roux, La contamination du monde. Une histoire des pollutions à l'âge industriel (Le Seuil 2017).

15 Council Regulation (EC) No 1907/2006 of the European Parliament and of the Council on the Registration, Evaluation, Authorisation and Restriction of Chemicals (REACH) [2006] OJ L 396/1. See Henri Boullier, Toxiques légaux: comment les firmes chimiques ont mis la main sur le contrôle de leurs produits (La Découverte 2019) 115.

${ }^{16}$ Because this article focuses on the life cycle of minerals, the sink refers to the growing trade of electronic waste, containing valuable elements, including gold, silver, palladium, platinum, aluminium, copper, yttrium, lanthanum, terbium, neodymium, gadolinium, praseodymium, etc. For a general discussion on sinks, see Jennifer Gabrys, 'Sink: the dirt of systems' (2009) 27(4) Environment and Planning D: Society and Space 666.

${ }^{17}$ Olga Kuchinskaya, The politics of invisibility: Public knowledge about radiation health effects after Chernobyl (MIT Press 2014).
} 
Discard Studies reveal that transnational laws ${ }^{18}$ pertaining to waste management disproportionally address the household and municipal solid waste, which amounts to less than 10 percent of all waste created, while seldom tackling the majority, some 90 percent, of upstream industrial pollution. ${ }^{19}$

Typically, the problem of e-waste is cast as a post-consumption disposal issue. Yet formatting it that way brackets out all the practices of resource extraction, design, manufacturing, distribution, and use from which far more waste arises. Postconsumer recycling will never solve the problem of waste arising from electronics production. ${ }^{20}$

This asymmetry of perception is framed by legal (dis)orderings. ${ }^{21}$ Transnational laws, such as bilateral investment treaties, protocols regulating global pollution and regional regulatory mechanisms ${ }^{22}$, organise the political economy of waste according to industrial policies, vested interests and political priorities, which carry the bulk of toxic waste 'out of sight and out of mind'. The classification of waste across asymmetric legal spaces is central to the circulation of some types of waste and the immobilisation of other types of waste across the life cycle of metal. Because of the importance of mineral extraction for global value chains, transnational law fragments regimes of environmental responsibility by rendering mineral waste relatively invisible, while concentrating regulatory efforts on the recovery of electronic waste.

International Law has an equivocal definition of waste, drawn from the general understanding of waste as a 'substance' or 'object' to be 'discarded' or 'disposed of'. ${ }^{23}$ A first definition of waste, derived from continental civil law, suggests that a disposable object may be synonymous to an abandoned object: once the classic trilogy of usus, fructus, abusus is consummated, the object becomes res nullius. ${ }^{24}$ Industrial and mining waste is often left abandoned on site, dumped in the peripheries of the extractive economies: res nullius, res derelicta. As we shall see, this 'linear' definition corresponds to the negative externalities of foreign extractive corporations operating in the Global South.

18 Transnational law of waste is an umbrella term for all environmental and trade laws regulating waste, which transcend national frontiers and include but are not limited to public and private international law. Transnational investment law, for instance, implies that regulation pertaining to mineral waste management can be diffused globally without necessarily involving traditional international law between Nation States. See Terence Halliday \& Gregory Shaffer (eds), Transnational legal orders (Cambridge University Press 2015) 4.

${ }^{19}$ Lepawsky (n 4). See also the research network Discard Studies Social studies of waste, pollution \& externalities, online https://discardstudies.com/.

${ }^{20}$ Ibid, 10.

${ }^{21}$ See Halliday \& Shaffer (n 18).

22 See Protocol on Civil Liability and Compensation for Damage Caused by the Transboundary Effects of Industrial Accidents on Transboundary Waters (adopted 21 May 2003) ECE/MP.WAT/11-ECE/CP.TEIA/9; Basel Protocol on Liability and Compensation for Damage Resulting from Transboundary Movements to the Convention on the Control of Transboundary Movements of Hazardous Wastes and their Disposal, (adopted 10 December 1999) UNEP/CHW 1/WG/1/9/2; Council Regulation (EC) 166/2006 of 18 January 2006 Concerning the Establishment of a European Pollutant Release and Transfer Register and Amending Council Directives 91/689/EEC and 96/61/EC [2006] OJ L 33/1, Article 11.

${ }^{23}$ Basel Convention on the Control of Transboundary Movements of Hazardous Wastes and Their Disposal (adopted 22 March 1989, entered into force 5 May 1992) 1673 UNTS 57 (Basel Convention), Articles 2(1) and 10(2); Bamako Convention on the Ban of the Import into Africa and the Control of Transboundary Movement and Management of Hazardous Wastes Within Africa (adopted 20 January 1991, entered into force 13 December 1998) 2101 UNTS 177, Artcile 1(1); Convention to Ban the Importation into Forum Island Countries of Hazardous and Radioactive Wastes and to Control the Transboundary Movement and Management of Hazardous Wastes within the South Pacific Region (adopted 16 September 1995, entered into force 21 October 2001) 2161 UNTS 91, Article 1.

${ }^{24}$ Martine Rémond-Gouilloud, Du droit de détruire: essai sur le droit de l'environnement (Presses Universitaires de France 1989) 107. 
By contrast, a second definition of waste, derived from English common law, claims that what can be 'disposed of' includes the selling for gain, which subjects the disposable object to mercantile transactions and economic exploitation. ${ }^{25}$ This 'circular' definition pertains to the worldwide commodification of recyclable waste in industrialised economies.

This article thus relies on a binary definition of waste as the disposable residue of our activities, which is either abandoned and forgotten or converted into a positive value. ${ }^{26}$ Once we accept the binary definition of waste, we realise that transnational governance co-produces a soft law of ecological imperceptibility, while simultaneously promoting a perceptible regime of recyclable commodities. Depending on market preference, the transnational governance of waste is either a 'negative' concealment tool or a 'positive' lustration tool.

Each year, mining operations generate extreme volumes of mineral waste, which are unknown in detail. According to the Mining, Minerals, and Sustainable Development Project, there are approximately 3,500 active mining waste sites worldwide, consisting of waste rock dumps and tailing dams. ${ }^{27}$ The estimated worldwide generation of solid wastes from the primary production of mineral and metal commodities is over 100 billion tonnes per year, ${ }^{28}$ compared to the 500 million tonnes of e-waste produced annually. ${ }^{29}$ Statistically, the amount of e-waste generated at the sink of the life cycle of metal corresponds to 0.5 percent of the total volume of mining waste generated at the source.

And yet, the scope and stringency of e-waste legislation worldwide is far greater than the regulations on waste generated by the mining sector. In 2017, 66 percent of the world population was already covered by e-waste management laws, an increase from 44 percent that were covered in $2014 .{ }^{30}$ By contrast, the mining industry lacks stringent international mining and environmental standards. Though the 1996 Aarhus Convention calls on all parties to establish national pollution registers, there is no internationally agreed upon strategy for the collection of mining emission data. ${ }^{31}$ The erosion of the efficacy of the information disclosure obligations reflects the dominance of market liberal perspectives over social welfare in environmental law. ${ }^{32}$

${ }^{25}$ Nicolas de Sadeleer, 'The Concept of Waste' in Thomas Ormond, Martin Führ and Regine Barth (eds), Environmental Law and Policy at the Turn to the 21 st Century - Liber Amicorum Betty Gebers (Lexxion 2006), 243, 249-250.

${ }^{26}$ Jean-Jacques Laffont, 'Externalities' in Steven Durlauf and Lawrence Blume (eds), The New Palgrave Dictionary of Economics ( $2^{\text {nd }}$ edn, Palgrave Macmillan 2008).

${ }^{27}$ International Institute for Environment \& Development, 'MMSD [Mining Minerals and Sustainable Development Project], Final Report' (Earthscan Publications Ltd 2002) online: https://www.iied.org/mmsd-final-report.

${ }^{28}$ John Rankin, Minerals, metals and sustainability: meeting future material needs, Commonwealth Scientific and Industrial Research Organisation (CSIRO 2011).

${ }^{29}$ Silpa Kaza et al, 'What a waste 2.0: a global snapshot of solid waste management to 2050' (World Bank Publications 2018).

30 Cornelius Baldé et al, 'The Global E-waste Monitor 2017', (United Nations University, International Telecommunication Union and International Solid Waste Association) online: https://www.itu.int/en/ITU-D/ClimateChange/Documents/GEM\%202017/Global-E-waste\%20Monitor\%202017\%20.pdf.

31 Convention on Access to Information, Public Participation in Decision-Making and Access to Justice in Environmental Matters (adopted 25 June 1998, entered into force 30 October 2001) 2161 UNTS 447; Kristina Saarinen, 'A method to improve the international comparability of emission data from industrial installations' (2003) 6(4) Environmental Science \& Policy 355.

32 Michael Mason, 'So far but no further? Transparency and disclosure in the Aarhus Convention' in Aarti Gupta, Michael Mason (eds), Transparency in Global Environmental Governance: Critical Perspectives (MIT Press 2014) 83,85 . 
Moreover, the Protocol on Pollutant Release and Transfer Registers, signed by 38 States and in force since 2009, is not designed to reduce pollution levels, but to enhance public access to information through the establishment of coherent, integrated, nationwide pollutant release and transfer registers. Resource-rich countries of the world, specifically Canada, the United States, China, Latin American and African states, are not parties to the Protocol.$^{33}$ Finally, many voluntary initiatives void of legal stringency, such as the Extractive Industries Transparency Initiative ${ }^{34}$, illustrate the weakness of public governance structures and their numerous failings at documenting, coordinating, and policing wrongful environmental behaviours at the local, national, regional, and global levels.

Mining waste regulation rests on definitional misunderstandings, miscalculated environmental costs, and methodological inconsistencies. The lack of full disclosure of mining flows is one of the most crucial limitations in advancing towards a comprehensive regime of mining pollution law. Without knowledge of the volume and spatial distribution of mining leakage, it is impossible to develop coherent strategies to mitigate ecological harm. Whereas e-waste management reforms have taken place at the international level (Basel technical guidelines and Ban amendment of 2019 ${ }^{35}$ ), the regional level (the 2012 European Union (EU) Waste Electrical and Electronic Equipment Directive (WEEE) directive ${ }^{36}$ ) and domestic level (Canadian E-waste Stewardship program and United States legislation, for example ${ }^{37}$ ), the mining waste reforms on the contrary have been frozen in time by the transnational legal activism of mining corporations.

Canadian historian Michelle Murphy frames the ways in which the politics of knowledge production and the process of materialisation render certain things obscured while others acquire and retain visibility within scientific communities and society. ${ }^{38}$ Murphy also examines this concept in relation to industryfunded research, which produces what she calls 'regimes of imperceptibility' that obscure and entrench the power of corporations over local communities and remove them from visible scenes. Inspired by her work, we share the view that various regimes of transnational law design the circular economy as a 'regime of perceptibility' at the sink, while perpetuating a 'regime of imperceptibility' at the source of the linear extractive economy. ${ }^{39}$ In the following sections we address the production and reproduction of regimes of (im)perceptibility both at the source and the sink of linear and circular economies.

\section{Regimes of e-waste perceptibility in circular economies}

\footnotetext{
33 Protocol on Pollutant Release and Transfer Registers to the Convention on Access to Information, Public Participation in Decision-Making and Access to Justice in Environmental Matters (adopted 21 May 2003, entered into force 8 October 2009) 2626 UNTS 119.

${ }^{34}$ Extractive Industries Transparency Initiative, online: https://eiti.org/.

35 Technical guidelines on transboundary movements of electrical and electronic waste and used electrical and electronic equipment, in particular regarding the distinction between waste and non-waste under the Basel Convention (E-waste) (10 July 2015) UNEP/CHW.14/7/Add.6/Rev.1, adopted by the Conference of the Parties to the Basel Convention on the Control of Transboundary Movements of Hazardous Wastes and Their Disposal, Fourteenth meeting Geneva, 29 April-10 May 2019.

${ }^{36}$ Council Directive 2012/19/EU of the European Parliament and of the Council of 4 July 2012 on Waste Electrical and Electronic Equipment (WEEE) [2012] OJL 197/38.

${ }^{37}$ See Electronics Product Stewardship Canada, online: https://epsc.ca/; California Electronics Waste Recycling Act 2003, 14 CCR $\S 18660.5$.

${ }^{38}$ Michelle Murphy, 'Uncertain exposures and the privilege of imperception: activist scientists and race at the US Environmental Protection Agency' (2004) 19 Osiris 266.

${ }^{39}$ Sara Ann Wylie, Fractivism: Corporate bodies and chemical bonds (Duke University Press 2018).
} 
E-waste is an amorphous legal category that sits uneasily between conflicting transnational legal regimes. On the one hand, e-waste has been globally traded as the main ingredient of the circular economy. ${ }^{40}$ On the other hand, the Basel regime on the transboundary movement of waste defines e-waste as a discarded object to be managed by sound environmental practices. Over the last three decades, as the market for secondhand electronic equipment soared, e-waste has progressively garnered public attention and been subjected to the legal scrutiny of formal transnational regimes. Therefore, e-waste has been encased into two parallel dynamics of market externality and market commodity, fragmenting as well as expanding the legal consciousness of the e-waste problem between two legal orders: the legal space of environmental law represented by the Basel Convention, and the legal space of market commodities adjudicated by the circular economies. Initially conceived as an environmental problem to be addressed (matter of concern), e-waste has now entered the global metal supply chain (matter of fact).

\section{a) Matter of concern: the perceptibility of e-waste regulation}

Historically, the e-waste regime emerged as an international problem to be addressed with the entry into force of the Basel Convention in 1992. ${ }^{41}$ Though the Basel Convention is not a specialised international treaty pertaining to e-waste, it nonetheless framed the debate and controversies around the management of e-waste. The Convention does not determine a legally binding cap on waste transfer across jurisdictions. Provided the host State consents and is notified by the exporting State, hazardous waste may legally be traded on the international market. In short, there is no ban of waste transfer, rather a regulatory platform for exchange. The Convention imposes on member states a duty of reporting their levels of hazardous wastes (Article 13.3), yet never achieved its general aim of 'eliminating the generation of hazardous wastes... in an environmentally sound manner'. ${ }^{42}$

At the Basel Conventions Conference of the Parties (COP), member States long failed to adopt universal technical guidelines on the definition of electronic discards, partly because of disagreements over their material complexity. ${ }^{43}$ E-waste often evaded the category of hazardous waste and fell outside the purview of the Basel Convention. ${ }^{44}$ This meant that sovereign states, following the World Trade Organization rules of free trade, were able to claim the legality of their e-waste export and import with minimal oversight. The e-waste trade economy revealed what was 'hazardous' in some European countries was elsewhere - in Egypt or China for example_-defined as a 'recyclable' commodity or a 'reusable object'. ${ }^{45}$

These definitional inconsistencies and loopholes in the transnational regime of e-waste regulation magnified the importance of tackling the e-waste problem from a sturdier environmental perspective. It is crucial to remind the reader about the dual regime of (im)perceptibility here. The international effort to

\footnotetext{
${ }^{40}$ E-waste has been historically dominated by the criminal underworld of 'midnight movers', which evacuated two thirds of e-waste on the informal market economy. See Rémond-Gouilloud (n 24).

${ }^{41}$ Basel Convention (n 23).

42 Ibid Art 10(2)(c).

${ }^{43}$ Sabaa Ahmad Khan, 'E-products, E-waste and the Basel Convention: Regulatory Challenges and Impossibilities of International Environmental Law’ (2016) 25(2) Review of European Comparative \& International Environmental Law 248.

${ }^{44}$ Josh Lepawsky, 'Are We Living in a Post-Basel World?' (2015) 47(1) Area 7.

45 Jamie Furniss, ‘Alternative Framing of Transnational Waste Flows’, (2015) 47(1) Area 24.
} 
address the growing worldwide e-waste trade further drove the concern about the mineral waste to the background of international legal consciousness.

Thus, when the Ban amendment annexed to the Basel convention finally entered into force in 2019, the legal perceptibility of e-waste was inflated once more. The amendment essentially bans the export of hazardous waste from 'developed countries' (Organisation for Economic Co-operation and Development, EU member states, Liechtenstein) to 'developing countries'. ${ }^{46}$ Thus, additional bureaucratic conflict over the interpretation of key defining terms of e-waste generated a new round of debate, substantiated by heavy lobbying by the industry to shelter e-waste from the Ban amendment. The same year, the Basel convention technical guideline on transboundary movement of electronic waste was adopted by the COP. Pursuant to paragraph 32(b) of the guidelines, used electronic equipment can still move across jurisdictions when the equipment is destined for failure analysis, or for repair or refurbishment by the same owner. ${ }^{47}$

As a result of these technical and legal restraints, e-waste as a commodity has been diverted towards regional and domestic circular economies. After the 2019 entry into force of the Ban amendment and Technical guidelines on e-waste, the Basel regime prompted a heightened perception of the e-waste issue within national boundaries, where large industrial manufacturers aimed to economically and politically capitalise on urban e-waste mining.

By diverting the issue of waste regulation to the technical expertise of e-waste, sovereign States and corporations have espoused a managerial ethos, which distracts 'civic epistemologies' from the attention that mineral production deserves. ${ }^{48}$ Initially conceived as a response to a growing environmental concern over the increasing volume of toxic waste trade, the Basel Convention and its additional protocols internalise an economic rationale as the underlying functional logic of the global waste management system. ${ }^{49}$

\section{b) Matter of fact: the implementation of the regime of e-waste perceptibility}

The implementation of the regime of e-waste perceptibility was the result of the significant rise in transboundary e-waste commodity transfer. Between 1992 and 2019, the average life of consumer electronic devices progressively decreased as a result of changes in equipment features, capabilities and planned obsolescence. ${ }^{50}$ This created a large stream of obsolete electronic equipment, which is expected to reach 500 million tonnes by the end of $2020 .{ }^{51}$ In response to the rise of post-consumer waste, the waste management sector developed greater waste recycling capacity.

\footnotetext{
${ }^{46}$ Amendment to the Basel Convention on the Control of Transboundary Movements of Hazardous Wastes and their Disposal (adopted in 22 September 1995, entered into force 5 December 2019) UNEP/CHW.3/35.

${ }^{47}$ Technical guidelines (n 35).

${ }^{48}$ Sheila Jasanoff, Designs on nature: Science and democracy in Europe and the United States (Princeton University Press, 2011).

${ }^{49}$ Freyja Knapp, 'The birth of the flexible mine: Changing geographies of mining and the e-waste commodity frontier' (2016) 48(10) Environment and Planning A: Economy and Space 1889.

${ }^{50}$ Sabine LeBel, 'Fast machines, slow violence: ICTs, planned obsolescence, and e-waste' (2016) 13(3) Globalizations 300.

${ }^{51}$ Kaza et al, (n 29); Baldé et al, (n 30).
} 
E-waste tracking and participatory sensing projects render urban waste management more visible. ${ }^{52}$ High-tech monitoring techniques are now used to track and manage e-waste at the sink of global consumption, such as 'automated means of cellular scanning, drones, cameras, sensors combined with actuators, and robotics in the recycling warehouses. They assist with inventory assessment, classification, and sorting. ${ }^{53}$

Parallel to the technical innovations in the circular economy, new regulations have created a new infrastructure of e-waste monitoring, which include a trail of contractual papers, certification, evaluation, invoices and safe packaging, which all guarantee the formal handling of the hazardous material. ${ }^{54}$ To illustrate such a regime of e-waste perceptibility, we focus on two regions that have undergone the highest levels of circular integration, Europe and Asia.

\section{Europe}

Electronic waste is currently governed by a European Community directive, the WEEE Directive. ${ }^{55}$ The Directive is a broad framework for the re-use, recycling and recovery of e-wastes for the benefit of European manufacturing. ${ }^{56}$ In 2016, circular activities such as repair, reuse or recycling generated almost $€ 147$ billion in value added, while standing for around $€ 17.5$ billion worth of investments ${ }^{57}$ The EU has recently adopted a revised legislative framework to modernise waste management systems, which entered into force in July $2018 .^{58}$ The Directive harmonises definitions and calculation methods and clarifies the legal status for recycled materials and by-products. The following quote conveys the heightened regime of perceptibility at the EU level:

The Commission is supporting and engaging with Member States in the implementation of the waste legislation to increase visibility and understanding of circular economy opportunities in those Member States that have the biggest challenges in meeting their recycling targets. ${ }^{59}$

The same year, the Urban Mine Platform was launched to help build a centralised database of information on stocks, flows and treatment of WEEE. Increased recycling targets for municipal waste encourage circularity of electronics metals. Many States have supported initiatives of urban mining, which endeavour to extract and purify precious metals taken from waste streams. The e-waste recovered from one million smartphones is estimated to deliver $34 \mathrm{~kg}$ of gold, 14,000 kg of copper, $15 \mathrm{~kg}$ of palladium, and $350 \mathrm{~kg}$ of silver. To further put this into perspective, one tonne of smartphones can yield up to 300 times more gold

\footnotetext{
${ }^{52}$ Monitour E-trash Transparency Project, 'How does e-waste travel across the world after disposal?' (Basel Action Network and MIT Senseable City Lab, 2012) online: http://senseable.mit.edu/monitour/.

${ }^{53}$ Rolien Hoyng, 'Aggregations of the opaque: Rethinking datafication and e-waste' (2019) 24(4) First Monday 1.

${ }^{54}$ See Technical guidelines (n 35).

${ }^{55}$ WEEE (n 36).

${ }^{56}$ Nicky Gregson \& Mike Crang, 'From Waste to Resource: The Trade in Wastes and Global Recycling Economies', (2015) 40 Annual Review Environment and Resources 151.

${ }^{57}$ See European Commission, 'Private investments, jobs and gross value added related to circular economy sectors' (Eurostat) online:

https://ec.europa.eu/eurostat/tgm/refreshTableAction.do?tab=table\&plugin=1\&pcode=cei_cie010\&language=en.

${ }^{58}$ Directive (EU) 2018/851 of the European Parliament and of the Council amending Directive 2008/98/EC on waste [2018] OJ L 150/109.

59 Report from the Commission to the European Parliament, the Council, The European Economic and Social Committee and the Committee of the Regions on the implementation of EU waste legislation, including the early warning report for Member States at risk of missing the 2020 preparation for re-use/recycling target on municipal waste, COM (2018) 656 final. Emphasis added.
} 
than one tonne of gold ore. ${ }^{60}$ Considering the high stakes, EU Member States incorporate the new closedloop business model by modernising their recycling capabilities. For example, a major smelter company Umicore, headquartered in Belgium, turned its business model from highly polluting smelting to an ewaste-processing urban mining operation. ${ }^{61}$

\section{Asia}

In Asia, the post-consumer waste transfer and waste mining economy has led to the establishment of International Recycling Zone, where certified tax-free recycling plants process post-consumer waste in EcoParks. As the circular economy gains traction, solid waste management at the sink of the economy is made visible by transnational industrial cooperation, involving States, corporations and municipalities. Underlining this evolution, a new generation of preferential waste-trade regulations has emerged in the Pacific. In the last decade, Japan has concluded a series of bilateral treaties with Asian countries (Singapore, Malaysia, the Philippines, Thailand, Vietnam), and most recently with China. An agreement between Tokyo and Beijing was formalised on 7 May 2008, which forged an economic partnership on waste transfer and mining. The agreement set up an International Recycling Zone in the Ziya Circular Economy Industrial Park, which unites the Eco-Cities of Kitakiyushu (Japan) and Tianjin/Guangdong (China). Under the joint venture, Chinese companies salvage the embedded value from Japanese discards, reprocess them and send them back to Japanese manufacturers.

At the Chinese national level, urban mining schemes are designed to reclaim secondary resources from urban wastes and obsolete materials and mitigate China's resource scarcity. The Government initiated an Urban Mining Demonstration Bases (UMDBC) programme in May 2010 to operationalise urban mining. ${ }^{62}$ It is estimated that the annual recycling capacity is reaching 45 million tons, which significantly increases the rates of e-waste collection and recycling. ${ }^{63}$ One flagship UMDBC is the Tianying Industrial Park located in Jieshou, Anhui Province, recovering lead from monitors and TVs with Cathode-ray tube displays. Elsewhere, in Jinsheng Industrial Park in Linyi of Shandong Province, the amount of copper and metal collection reaches 1.74 million tons annually. ${ }^{64}$

As the establishment of international and domestic recycling zones in Europe and Asia demonstrates, the circular economy emphasises waste management at the sink of the metal life cycle. Transnational law has legalised a regime of perceptibility of e-waste, yet by the same token has rendered invisible other types of waste generated by the electronics sector. While the volume of e-waste recovery is on the rise, as a matter of fact it still pales in comparison to the level of mineral production at the source, which provides the essential ingredients to manufactured electronics.

\section{Regimes of industrial waste imperceptibility in linear economies}

60 Bianca Nogrady, 'Your old phone is full of untapped precious metals' BBC Future (18 October 2016) online: https://www.bbc.com/future/article/20161017-your-old-phone-is-full-of-precious-metals.

${ }^{61}$ Nigel Roome \& Victoria Jadot, 'A Case of Radical Reinvention: Umicore' in Gilbert Lenssen \& Craig Smith (eds), Managing Sustainable Business (Springer 2019) 519.

${ }^{62}$ Hua Zhou, 'Urban mining demonstration base: the development trend of recycling industry' (2014) 7 Recyclable Resource Circular Economy 21.

${ }^{63}$ Yuan $\mathrm{Hu} \&$ Mark Poustie, 'Urban mining demonstration bases in China: A new approach to the reclamation of resources’ (2018) 79 Waste management 689.

64 Ibid. 
The same transnational legal system that at the sink rendered post-consumer waste visible, by contrast, keeps extractive waste at the source 'out of sight, out of mind' ${ }^{65}$ Since the establishment of the Convention on the Settlement of Investment Disputes in 1966 and the subsequent adoption of free trade policies in Latin America by what came to be known as the Washington Consensus, the investment in mineral extraction has created a surge of transnational extractive operations across the world. ${ }^{66}$

\section{a) Matter of fact: the volume and toxicity of extractive waste at the source}

\section{Volume}

Hard rock metal mining waste commonly consists of overburden (surface vegetation and soil that covers an ore body), waste rock (rock that needs to be removed to access the ore) and tailings, the finely ground remains of crushed ore from which the target mineral has been removed. Waste to product ratios, or 'stripping ratios', vary by ore body. They can be as high as 99 tons of waste per ton of copper, and 91 tons of waste for an ounce of gold.

On average, for each ton of metal extracted from ores, 2 to 12 tons of overburden material is removed as waste. In Chile, 1.5 million tons of tailings are produced every day. ${ }^{67}$ South African mining companies in 2013 produced 562,000 times as much waste as gold. ${ }^{68}$ According to the EU Data Centre on Waste for 2010, around 60 percent of the waste generated by 29 European countries consisted of mineral waste and soil, mainly from activities in the mining sector. ${ }^{69}$

\section{Toxicity}

Mine waste is environmentally hazardous by virtue of its volume, often causing siltation or smothering of surface water sources. A further source of toxicity for surface and ground water derives from sulphides as well as metals - such as cadmium, copper, iron, lead, manganese, mercury and silver - that may occur naturally in the ore body. Oxidised sulphides in contact with water produce sulfuric acid and accelerate metal leaching from mine waste.

Dumping mine tailings into rivers and streams causes increased sedimentation, turbidity, flooding, contamination of floodplain sediments, and in some cases the burial of large swaths of tropical lowland rainforests and mangroves with a veneer of waste, causing dieback of vegetation on a large scale. ${ }^{70}$

\section{b) Matter of concern: the regime of imperceptibility at the source}

International norms in general, and international environmental law in particular, have proven ineffective in monitoring the dissemination of mining waste across ecosystems. Firstly, this is because many

\footnotetext{
${ }^{65}$ Susan Marks, 'Law and the production of superfluity' (2011) 2(1) Transnational Legal Theory 1.

${ }^{66}$ Maristella Svampa, 'Commodities consensus: Neoextractivism and enclosure of the commons in Latin America' (2015) 114(1) South Atlantic Quarterly 65.

67 "With 1.5 million tons of residue created per day, Chile is the world leader in mining waste." Agence France Presse, 'Chile's mining waste poses silent threat to humans on multiple fronts', 25 July 2019.

${ }^{68}$ See South African Chamber of Mines online: https://www.mineralscouncil.org.za/.

${ }_{69}$ European Environmental Agency, 'Waste: a problem or a resource?' online: https://www.eea.europa.eu/signals/signals-2014/articles/waste-a-problem-or-a-resource.

${ }^{70}$ Bernd Lottermoser, Mine Wastes: Characterization, Treatment, and Environmental Impacts ( ${ }^{\text {rd }}$ edn, Springer 2010) 229-33.
} 
conventions governing liability for the transboundary movement of waste have not yet entered into force. ${ }^{71}$ Secondly, even when conventions are in place, substantial limitations exist regarding their scope. For instance, the UN Convention on the Law of the Sea, which protects coastal States against risks posed by High Risk Vessels, does not effectively protect marine life from the pollution dumped by coastal States. ${ }^{72}$ Similarly, the International Convention for the Prevention of Pollution from Ships (MARPOL) is illequipped to tackle the mining problem at the source simply because it overlooks the metabolic rift of tailing ponds, which—inadvertently or by design — travel from the telluric source to the thalassic sink. ${ }^{73}$

Although the 1996 London Protocol to MARPOL effectively prohibits dumping of mine tailings at sea, the Protocol does not prohibit Submarine Tailings Disposal (STD), which is a discharge from land. The International Maritime Organization has issued guidelines to prevent land-based marine disposal, but STD has become a common practice throughout the mining industry worldwide. As early as 1971, coastal mining companies have submerged pipes to dispose of their mine tailings into the sea. ${ }^{74}$ Since then, the mining industries from the capital-exporting States have increasingly used the coastal regions of host States as mine waste dumps. ${ }^{75}$ Active mines using STD are located in Papua New Guinea, Turkey, Indonesia, Chile and Norway. STD occurs routinely off the coast of developing countries by companies headquartered in developed countries, where such disposal methods would be politically unacceptable. ${ }^{76}$ One example is the 'world class' Ramu nickel-cobalt mining operation led by a consortium of Canadian, Australian and Chinese companies on the coast of Papua New Guinea, which disperses its tailings in the sea and causes toxic exposure to ecosystems and marine life in multiple ocean layers, introducing to the sea and marine biota toxic metals and chemicals. ${ }^{77}$

Current STD incidences show the insufficient national and transnational environmental regulation to effectively prohibit mining pollution at sea. Even some environmental research bodies such as the Scottish Association for Marine Science are actively paid by the World Bank to produce a set of guidelines to assist governments in setting conditions for marine dumping of mine waste. ${ }^{78}$ The extractive industry has 'created a regime of imperceptibility in which the tools and infrastructures of environmental protection actually function to make hazards less perceptible. ${ }^{, 79}$

Even when primary pollution sites are bound by environmental laws, they may be difficult to monitor. In Canada, home to 75 percent of the world's mining company headquarters, the Metal and Diamond Mining Effluent Regulations are designed to limit the environmental impact of mining operations.

\footnotetext{
${ }^{71}$ See: Protocol on Liability and Compensation for Damage resulting from Transboundary Movements of Hazardous Wastes and their Disposal (n 22); Protocol on Civil Liability and Compensation for Damage Caused by the Transboundary Effects of Industrial Accidents on Transboundary Waters (n 22).

${ }^{72}$ United Nations Convention on the Law of the Sea (adopted on 10 December 1982, entered into force 16 November 1994) 1904 UNTS 320.

${ }^{73}$ Protocol of 1978 relating to the International Convention for the prevention of pollution from ships, 1973 (with annexes, final act and International Convention of 1973) (adopted 17 February 1978, entered into force 2 October 1983) 1340 UNTS 61 (1983).

${ }^{74}$ Catherine Coumans, 'Into the deep: science, politics and law in conflicts over marine dumping of mine waste' (2018) 68 International Social Science Journal 303.

${ }^{75}$ Ibid.

${ }^{76}$ Ibid.

${ }^{77}$ Mining Data Solutions, 'The Kurumbukari (Ramu) Mine', online: https://miningdataonline.com/property/3323/Kurumbukari-(Ramu)-Mine.aspx.

${ }^{78}$ Lindsay Vare et al, 'Scientific considerations for the assessment and management of mine tailings disposal in the deep sea' (2018) 5 Frontiers in marine science 17.

${ }^{79}$ Wylie (n 39), 286.
} 
However, the limited scope of these mechanisms has resulted in weak governance of mining waste at the industrial and federal levels. This can be detected in regulators' over-reliance on 'scientific' models, 'technical guidelines' and arguments developed by industry consultants. ${ }^{80}$ In 2019, Canada's environment commissioner found Canada's federal environment departments failed at monitoring the waste dumps of domestic mining companies. ${ }^{81}$

In addition to the weak governance of mining waste at the national level, a double standard of enforcement has allowed Canadian companies to benefit from lax environmental regulations abroad, extracting sizable profits while causing environmental and social harms on a scale rarely seen in Canada itself. $^{82}$ Outcomes are likely to differ when extractive operations are located in jurisdictions with substantially different levels of transparency, public accountability, and corruption.

\section{The imperceptibility of mining waste under investment regimes}

Whereas the Mining Codes of the investor state are legally transplanted in the extractive host states, the environmental safeguards - usually more stringent in the investor State's jurisdiction than in the host State's - are not transplanted. As the leading State in mining investment abroad, Canada signed free-trade agreements with host mining States, such as Chile (1997), Peru (2009), Columbia (2011), Columbia (2011) and Honduras (2014). Despite reference to principles of corporate social and environmental responsibility, these free-trade and investment treaties do not impose obligations on mining companies to minimise pollution. ${ }^{83}$

One clear example of this asymmetry is the Free Trade Agreement signed between Canada and Honduras. Before signing the agreement, Canada offered 'technical assistance' to reform Honduras' Mining Code which entailed recommendations to simplify regulatory processes, reduce environmental standards and limit the consultation rights of affected communities. According to Mining Watch Canada

the new law left water sources largely unprotected, allowed open pit mining even though it was opposed by 91 percent of Hondurans, provided for consultation only after concessions had been granted, denied public access to information about the technical and financial aspects of the mining projects, and allowed forced evictions resulting in the destruction of entire communities. ${ }^{84}$

Canada and Honduras later signed the Free Trade Agreement, which upon examination, does not implement environmental review standards or detail precise mining waste management processes, rather 'endeavours

\footnotetext{
${ }^{80}$ Coumans (n 74).

${ }^{81}$ Office of the Auditor General of Canada, Spring Reports of the Commissioner of the Environment and Sustainable Development to the Parliament of Canada, Report 2: Protecting Fish From Mining Effluent (April 2019) online: https://www.oag-bvg.gc.ca/internet/English/att_e_43314.html

82 Jordan Ardanz and Chris Fukushima, 'Deviations and Double Standards: Canadian Mining Practices at Home and Abroad' (International Justice and Human Rights Clinic, University of British Columbia School of Law 2019).

${ }^{83}$ Linda Reif, 'Canada and Foreign Direct Investment in Latin America and the Caribbean: Evolution of an International Investment Agreement Framework' (2010) 13 International Trade and Business Law Review 86, 113.

${ }^{84}$ Mining Watch Canada, 'Honduran Mining Law Passed and Ratified But the Fight is Not Over', (24 January 2013) online: http://www.miningwatch.ca/news/honduran-mining-law-passed-and-ratified-fight-not-over.
} 
to encourage voluntary best practices of corporate social responsibility by enterprises... to strengthen coherence between economic and environmental objectives. ${ }^{85}$

Another neglected factor that contributed to the invisibility of pollution embodied in trade is the incomplete waste assessment from official reports on the economic impact of free trade agreements. As a result, a comprehensive understanding of pollution driven by production at the source is currently limited. Although various environmental footprint databases and methods have been developed by academia, statistical offices, and international organisations to assess pollution and resources embodied in trade, they are still at their infancy and certainly not implemented by trade agreements. ${ }^{86}$ One important cause of this lack of monitoring is what scholars refer to as a 'race to the bottom', which implies competitive deregulation among host States with regards to environmental standards.

Furthermore, most of the environmental assessment is practiced on a voluntary basis by foreign corporate enterprises in the Global South, which increase the risk of submitting incomplete information on waste monitoring. In Honduras, major gaps in mining regulation have led to accusations by local communities of pollution by foreign companies, such as Canadian mining giant Goldcorp. ${ }^{87}$ Insufficiency of waste monitoring is not limited to Honduras. Throughout Latin America, the environmental regulation on waste monitoring is performed by for-profit consultants. Market-based science has repeatedly bred public distrust about the objectivity of information contained in the environmental reports drafted by corporations.

Since a substantial amount of waste is made invisible by official and corporate mining data, secondary accounts by community organiser, local advocacy platforms and non-governmental organisations can give an approximate idea of the magnitude of waste produced at the source. One such noteworthy effort is a report entitled 'Extractive casino', which illustrates the surge of lawsuits filed by corporations against Latin American states to limit their environment oversight over their own domestic extractive sector. ${ }^{88}$ Over the last two decades, global mining corporations have used the mechanism of the International Centre for Settlement of Investment Disputes (ICSID) against Latin American governments to demand compensation for public environmental policies that they claim reduce the value of their investments. This aggressive litigation tactic ensures that the State's response to waste generated within its boundaries subsides under the superior interest of foreign direct investors' right to extract resources. ${ }^{89}$

Whereas International Environmental Law emphasises rules of cooperation, International Trade Law has a more stringent level of legalisation, marked by a combination of binding rules and delegation to international arbitration, which overlook contamination at the source..$^{90}$ The environmental annexes to freetrade agreements lack enforcement mechanisms and advocate instead for a non-binding managerial ethos

\footnotetext{
${ }^{85}$ Agreement on Environmental Cooperation Between Canada and the Republic of Honduras (adopted 5 November 2013, entered into force 1 October 2014) online:

https://www.canada.ca/content/dam/eccc/documents/pdf/international-affairs/compendium/2018/batch-

11/agreement-environmental-between-canada-republic-of-honduras.pdf Article 10.

${ }^{86}$ Arnold Tukker, Stefan Giljum and Richard Wood, 'Recent progress in assessment of resource efficiency and environmental impacts embodied in trade' (2018) 22(3) Journal of Industrial Ecology 489.

${ }^{87}$ See: Inter-American Commission on Human Rights, 'The Impact of Canadian Mining in Latin America and Canada's responsibility' (2014).

${ }^{88}$ Jen Moore and Manuel Perez Rocha, 'Extraction Casino: Mining Companies Gambling with Latin American Lives and Sovereignty Through Supranational Arbitration' (CIEL, IPS, April 2019) https://ips-dc.org/wpcontent/uploads/2019/05/ISDS-Mining-Latin-America-Report-Formatted_April29.pdf.

${ }^{89}$ Ibid.

${ }^{90}$ Kenneth Abbott et al, 'The concept of legalization' (2000) 54(3) International organization 401.
} 
of care, by promoting 'the trade and investment of environmental goods and services'. ${ }^{91}$ On the one hand, financial disputes arising from bilateral investment treaties are to be adjudicated by international arbitration. On the other, disputes arising from parallel environmental cooperation treaties are only to be resolved through 'consultation' between countries, without recourse to an independent arbitrator. ${ }^{92}$

In this context, the 1994 North American Free Trade Agreement (NAFTA) entrenches an investment regime, which invisiblises corporate liabilities and their waste production. ${ }^{93}$ Ever since its entry into force, NAFTA's Chapter 11 on foreign investment rights has allowed Canadian and US companies to pocket millions of dollars using this mechanism against the Mexican State. One case is the Canadian mining company Blackfire, which in 2009 was faced by strong opposition to its presence in Chicomuselo, Mexico. Community members were speaking of broken promises, little or no consultation, social division, intimidation, violence, environmental degradations such as soil erosion, silt and mud contamination, dried up rivers, and dead cattle as more and more pastures were compromised downstream of the mine.

Under Chapter 11, only corporate entities are allowed to take action against the State, which effectively prevents States from seeking punitive damages from such corporation before an international court. As a result, victims of mining pollution may only resort to domestic courts in developing countries, where the judicial branch has systematically been accused of siding with big business. When the local municipality of Chiapas demanded the Mexican Federal Government to act immediately to cancel the mining concessions given to Blackfire, the Canadian State mounted a defence to support its national corporation. Instead of directing its resources to obtain a third-party perspective on the matter, the Trade Commissioner provided Blackfire with advice about how to sue the Government of Chiapas under NAFTA for having suspended mining operations.$^{94}$ An attrition of judicial avenues exists for States from the Global South, which are highly exposed to foreign mining waste dumping.

To conclude this section, foreign mining companies skilfully use transnational economic laws to keep national environmental regulators at bay. As a result of lobbying and international arbitration, public policies largely immunise the mining sector from the legal adoption of production restrictions, environmental taxation and sanitary regulation.

\section{Conclusion}

Our examination of transnational legalisation reveals a hierarchical architecture of (im)perceptibility between the sources of waste production and sinks of waste distribution. When waste acquires commodity value, transnational trade regulation renders it visible; yet when waste becomes an environmental hazard, the transnational legal order renders it invisible.

\footnotetext{
${ }^{91}$ See: Canada-Peru Environmental Cooperation Agreement, (adopted 29 May 2008, entered into force 1 August 2009) online: https://www.canada.ca/en/environment-climate-change/corporate/international-affairs/partnershipscountries-regions/latin-america-caribbean/peru/full-text.html signed in parallel to the Free Trade Agreement, Article $2[6]$.

${ }^{92} \mathrm{Ibid}$, Article 12.

${ }^{93}$ North American Free Trade Agreement (NAFTA) (adopted 17 December 1992, entered into force 1 January 1994) 107 Stat 2057, 32 ILM 289. On November 30, 2018, Canada, the United States, and Mexico signed an agreement to replace NAFTA with the Canada-United States-Mexico Agreement (CUSMA). This agreement renews the investorState arbitration regime in Chapter 14. See United States-Mexico-Canada Agreement Implementation Act, HR 5430; Public Law 116-113; 19 USC January 29, 2020 (US).

${ }^{94}$ Jennifer Moore \& Gillian Colgrove, 'Corruption, murder and Canadian mining in Mexico: the case of blackfire exploration and the Canadian embassy' (Mining Watch Canada, 2013).
} 
However, most visible mineral solid e-waste embodies a certain ratio of invisible industrial waste and a certain ratio of industrial mining waste is increasingly rendered visible as a recyclable commodity. ${ }^{95}$ This paradoxical co-production of waste (im)perceptibility is observed in the mining industry, where recent technological advancements increase the capacity to recycle tailing products such as minerals contained in waste rock. ${ }^{96}$ In the same vein, it can be said that environmental market incentives, such as carbon tax or cap and trade schemes, play a role in commodifying — hence visualising — waste at the source, the same way that waste is monetised at the sink. Nevertheless, by no means are these respectively recycling and commodification schemes addressing the magnitude of waste produced at the source. Admittedly, the production of industrial and mining waste shows no sign of decline since the introduction of such technologies. ${ }^{97}$

Innovations to recycle mining operations' tailings are constrained and marginal, notwithstanding the funnel of endowment by the industry in marketising its progress. Similarly, while cap and trade is a fast-growing regional market, it has been proven ineffective in visualising carbon dioxide emissions at the source. ${ }^{98}$ Although scrutinising these policies is beyond the scope of this article, failure of these schemes in reducing carbon dioxide emissions can be attributed to weak legalisation. ${ }^{99}$ When the carbon trade initiative is designed according to the invisible hand of the market, it resonates with prior pledges which have produced dubious results in the past. ${ }^{100}$ At the postconsumer sink, some residual unprocessed waste is impossible to recycle or commodify and is buried under another layer of imperceptibility. One example from the margins of the informal economy is the untreated waste generated by the circular economy itself, creating a feedback loop of waste accumulation in the periphery of high-tech recycling plants. ${ }^{101}$

Although further investigation is encouraged to disentangle the uncertainties and contradictions of the recycling economy, we hope this study contributed to raising awareness of the shifting boundaries of transnational waste regulation. The study of transnational law calls to attention the blind spots created by the legal categories of mining and electronic waste. Some recent policy recommendations have attempted to address such blind spots, calling for the creation of a specialised UN agency for strategic minerals. ${ }^{102}$ Another possible avenue of change recently suggested by a policy report of the OECD would be to ecologically tax transnational electronics corporations, instead of subsidising them. ${ }^{103}$

This special issue of Transnational Legal Theory called for an engagement with environmental law in the Anthropocene. The Anthropocene typically refers to a new geological epoch where humanity is

${ }^{95}$ Erica Schoenberger, 'Environmentally sustainable mining: The case of tailings storage facilities' (2016) 49 Resources Policy 119.

${ }^{96}$ Vladimir Golik, Vitaly Komashchenko and Vladimir Morkun, 'Innovative technologies of metal extraction from the ore processing mill tailings and their integrated use' (2015) 3 Metallurgical and Mining Industry 49.

${ }^{97}$ Daniel Hoornweg et al, 'Environment: Waste production must peak this century' (2013) 502(7473) Nature News 615.

${ }^{98}$ Rahel Aichele \& Gabriel Felbermayr, 'Kyoto and carbon leakage: An empirical analysis of the carbon content of bilateral trade' (2015) 97(1) Review of Economics and Statistics 104.

99 José Granados et al, 'Policies to reduce CO2 emissions: Fallacies and evidence from the United States and California' (2019) 94 Environmental science \& policy 262.

${ }^{100}$ Peter Dauvergne and Jane Lister, Eco-Business: A Big-Brand Takeover of Sustainability (MIT Press 2015).

${ }^{101}$ Carl Benedikt Frey, The Technology Trap: Capital Labor, and Power in the Age of Automation (Princeton University Press 2019).

102 Massachusetts Institute of Technology, 'Mission 2016: Strategic Mineral Management', online: https://web.mit.edu/12.000/www/m2016/finalwebsite/solutions/protocol.html.

${ }_{103}$ Organisation for Economic Co-operation and Development, 'Taxing Energy Use 2019: Using Taxes for Climate Action' (15 October 2019) online: http://www.oecd.org/tax/taxing-energy-use-efde7a25-en.htm. 
'literally making' the planet. ${ }^{104}$ Rather, we wish to argue that hierarchical and fragmented regimes of transnational law conceal the littering and breaking of the planet by some members of humanity. ${ }^{105}$ The Molysmocene $^{106}$ is a corollary neologism to the Anthropocene, which defines the permanent state of exceptional toxicity that we live in. Stratigraphically, anthropogenic deposits form a new layer of the earth crust on the top of the lithosphere. This crust of civilizational waste, we call the littersphere ${ }^{107}$ Rather than proposing a new stream of environmental law in the Anthropocene, we call for ecological law to radically address the systemic and institutional flaws of the littersphere. Ecological law offers a more responsive, sustainable, and just system of governance that better protects our interconnected, interdependent world. ${ }^{108}$

Ecological law is in line with structural reforms focused on strategies of degrowth, which gain traction in periods of global meltdown when critical inquiry into the vulnerability of free market societies becomes a public necessity. One such degrowth strategy would be to propose financial divestment from mass electronics manufacturing, henceforth reducing global mineral demand at the source of the global supply chain, which uninterrupted would exhaust the sink capacity of the earth. Furthermore, a reconsideration of $5 \mathrm{G}$ technology, which would require an overhaul of the entire electronic grid to satisfy this new high-speed communication platform, is essential. Such policy reforms require a serious reconsideration of the transnational legal structure, which has imposed a market-based approach to environmental concerns for the benefit of the mining and electronics industries.

${ }^{104}$ Simon Dalby, 'Environmental geopolitics in the twenty-first century’ (2014) 39(1) Alternatives 3.

${ }^{105}$ Giles Slade, Made to break: Technology and obsolescence in America (Harvard University Press 2009).

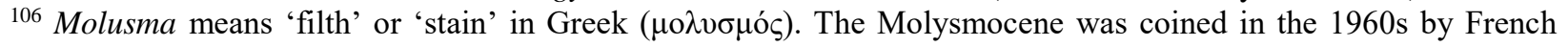
marine biologist Maurice Fontaine to refer to a future wasteland, an era which we now live in. See Tina Beigi, Olivier Barsalou and Michael Hennessy Picard, 'Welcome to the Molsymocene', (2017) Critical Legal Thinking 1.

107 Justin McBrien, 'Accumulating extinction: Planetary catastrophism in the Necrocene' in Elmar Altvater et al, Anthropocene or capitalocene? Nature, history, and the crisis of capitalism (Pm Press 2016) 116.

${ }^{108}$ Carla Sbert, The Lens of Ecological Law: A Look at Mining (Edward Elgar 2020); Ecological Law \& Governance Association, Oslo Manifesto for Ecological Law and Governance (2016), online: https://www.elga.world/oslomanifesto. 